International Journal of Physical Research, $9(2)(2021) 92-97$
International Journal of Physical Research
SPC
Website: www.sciencepubco.com/index.php/IJPR
Research paper

\title{
Thermodynamic constant of time passage
}

\author{
Mieczysław Dobija ${ }^{1}$, Jurij Renkas ${ }^{2}$ \\ ${ }^{1}$ Cracow University of Economics, Rakowicka St., 27, 31-425, Cracow, Poland ORCID No: 0000000306702313 \\ ${ }^{2}$ Cracow University of Economics, Rakowicka St., 27, 31-425, Cracow, Poland ORCID No: 0000-0001-7139-5458 \\ *Corresponding authorE-mail: dobijam@uek.krakow.pl
}

\begin{abstract}
The study of time has a long history and is still ongoing. The term formulated by Isaac Newton was coined in the 17th century, so naturally it could not relate to thermodynamics. Since the passage of time and aging are inalienable components of human experience, so Newton's concept of time was and is still alive. W.G. Leibniz and I. Kant mainly questioned the absoluteness of time. This paper introduces the definition of time and justifies the thesis that time is a thermodynamic process, flows uniformly, and the rate of passage of time is determined by a suitable natural constant.
\end{abstract}

Keywords: Thermodynamic; Time Passage; Constant.

\section{Introduction}

Time and the passage of time are issues that are still being debated and it is possible to distinguish three sides with differing views. The first one originates from Isaac Newton (1642-1727), the second one comes from Albert Einstein (1879-1955) and the third one, in which it is believed that time does not exist, started in antiquity, now has a prominent representative in the person of Julian Barbour, the author of the work "The End of Time. A New Revolution in Physics".

The authors of this article present the view that the common perception of the passage of time is grounded in the real world, and that the uniform passage of time that Newton spoke of is due to the existence of a thermodynamic constant that determines the rate at which time runs. We admit the rightness of Arthur Eddington (1882-1944), who in his style stated [Holt, 2018, p. 19] that there must be something real that causes the passage of time, so this concept should not be eliminated from scientific consideration:

(...) Arthur Eddington, one of the first physicists to grasp Einstein's relativity theory, declared that our intuitive sense of time's passage is so powerful that it must correspond to something in the objective world. If science cannot get purchase on it, one might say, well, so much the worse for science (...)

J.T. Fraser (1923-2010), founder of the International Society for Study of Time (http://www.studyoftime.org/), expressed his belief that the sensation of the passage of time is perhaps more poignant, profound and direct than any aspect of our existence. Moreover, time is profoundly connected with the functions of the mind; it is the only dimension of our inner life. This is a development of the opinion of I. Kant, who recognized time and its passage as an inalienable tool of the human mind. Accepting these premises we will show that the human feeling of time has its real basis, and that for a human being time flows evenly, independently of other events.

\section{Modification of Isaac newton's concept of time}

The original definition of time as captured in the work "Principia", is as follows:

Absolute, true, and mathematical time, in and of itself and of its own nature, without reference to anything external, flows uniformly and by another name is called duration. Relative, apparent, and common time is any sensible and external measure (precise or imprecise) of duration by means of motion; such a measure - for example, an hour, a day, a month, a year - is commonly used instead of true time.

I s a a c N e w t o n, The Principia. Mathematical Principles of Natural Philosophy, The Authoritative Translation by I. Bernard Cohen and Anne Whitman assisted by Julia Budenz, U n i ver s i t y o f C a 1 i f o r n i a P r e s s, 1999, p. 54

Wolfgang G. Leibniz (1646-1716) disagreed with the view of time as absolute, independent of anything. Leibniz was convinced that space and time were not real, but were relations between material objects and mathematical concepts. He considered time in the context of philosophy and monadology.

Like Leibniz, Immanuel Kant (1724-1804) guided by well-known aphorisms such as: "Without sensuality no object would be given to us, without intellect none would be conceived, concepts without sensory perceptions are empty, and perceptions without concepts are blind", he formulates an opinion about time and space. Time is a form of our sensuality, it is a form of the inner sense. He also recognized that time is empirically real. This opinion is largely confirmed by our definition of time. At that time thermodynamics had not yet developed, 
and yet Kant's understanding of the nature of time is extremely accurate, and additionally points to the inseparable connection between time and humanity.

Our definition of time follows the direction given by Newton and Kant but is clearly thermodynamic in nature. Therefore, identification of objects subject to the process of transformation is required. Time and these immaterial objects are defined by the following definition.

Time is the process of transformation of the stock of primary vital energy of modern man into the ability to perform work, i.e. personal human capital. The rate of passage of time is constant and independent of anything. This rate is determined by the constant $\mathrm{a}=0.08$ [1/year].

In this term, specific real elements appear, such as stock of vital energy, human capital, the process of transformation, and the uniformity of the process whose rate is determined by a natural constant. This term being in accordance with the idea of uniform flow of time, it reveals real objects mentioned by A. Eddington. Therefore time is not absolute, but it is passing evenly reflecting diminishing of the original stock of life forces and increasing of the power of human organism. Course of these processes is controlled by constant 0.08 [ $1 /$ year], and its unit of measure refers to astronomical calendar.

How the transformation of life's primary energy into what is generally called human capital works is illustrated by the three posted photographs beneath; of an infant, a one year old child and a two year old child. It can be seen that the use of $8 \%$ of the primary energy resource in the first year of life results in the fastest growth. In the second year, $8 \%$ calculated on the remaining $92 \%$ of the original energy resource also provides rapid growth, but slightly less.
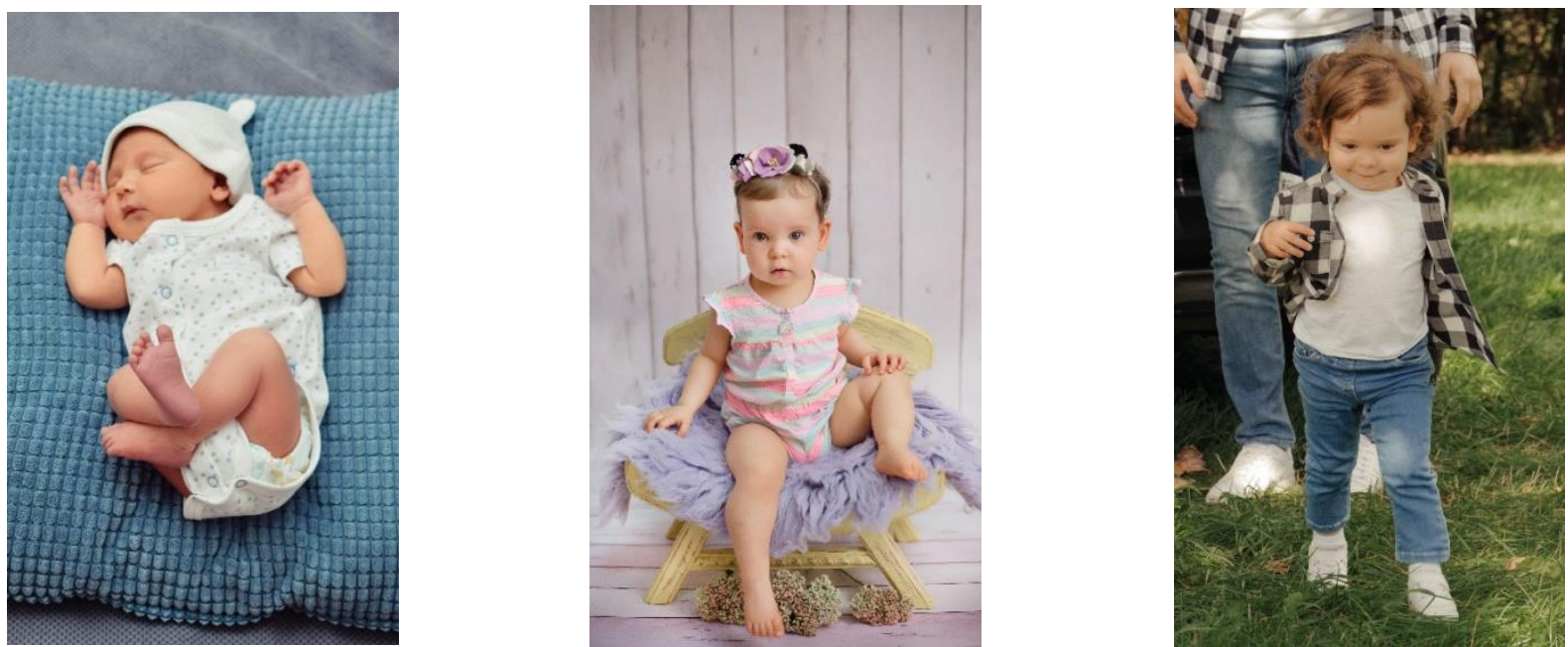

Photo. 1: Photographs* Showing the Transformation of Primary Life Energy into Human Capital.

* Photographs of my daughter Emilia Renkas are posted with my spouse's joint permission solely for use within this article. Any copying or publishing by third parties requires each time written consent of the parents.

On the other hand, it is known that it is difficult to discern differences in outward appearance when it comes to older people. We cannot distinguish whether a person is 50 or 51 years old.

The presented determination of time falls into the stream of research applying the knowledge of thermodynamics to the general theory of capital and, in particular, the theory of rewarding the work of human capital. These considerations are a continuation and development of the knowledge presented in the articles (Dobija, Renkas, 2020, 2021). In these articles, the existence and role of the thermodynamic constant necessary to explain many economic issues was documented. Currently, a theme related to the development of personal human capital, i.e. the human body and its ability to perform work, has emerged. Consideration shows that human capital is formed as a result of the transformation of the original stock of vital energy into this capital. Vital forces decrease and personal capital increases; the rate is determined by the constant $\mathrm{a}=0.08[1 /$ year $]$.

The original stock of vital energy decreases according to a recursive formula:

With $\mathrm{Z}_{0}=1.0, \mathrm{Z}_{\mathrm{t}+1}=\mathrm{Z}_{\mathrm{t}} \times \mathrm{e}^{-\mathrm{a}}$

For $\mathrm{t}=0,1,2, \ldots$, Where $\mathrm{t}$ is the number of astronomical years. In other words, $\mathrm{Z}_{\mathrm{t}}=\mathrm{e}^{\text {-at }}$.

The primordial resource of vital energy was already known in antiquity. Huai-Chin-Nan $(1984$, p. 45) writing about the essence of "qii" describes it as: "the primary vital energy (...) the primary energy of the body is like a hidden treasure that comes with life". This knowledge is specified by P. Pitchford (2010, pp. 82-83), indicating three sources of the qi energy. The first source called Yuan Qi is the primordial energy occurring in the determination of time. According to the ancient knowledge it is inherited from the parents and passed on to the descendant. The energy resource is limited and is used up over time. An unfavorable lifestyle leads to additional loss of this energy. The author was unfortunate to use the term "wear and tear" because this energy is transformed into a person's ability to do work. What can be seen with lack of health care is a faster physical aging process of the body.

Source two Gu Qi is the energy extracted from the food consumed, and source three Zong Qi is the energy from the air, extracted through the lungs and skin. It is interesting that according to the time determination, a person at the age of 65 has a residual primary energy of 0.0055 when the initial energy was 1.0. This is also the time of retirement of the employed. Maoshing Ni (1995, pp. 22-23) in his book "The Yellow Emperor's Classic of Medicine" discusses the successive 8-year stages of human development in terms of kidney energy (synonymous with vital energy) and states that:

By the sixty-fourth year, the tian kui dries up and the jing is depleted, kidney exhaustion, fatigue and weakness occur. (...) In old age, the organs are already weakened and their energy depleted, the bones become brittle, the tendons lose their elasticity, it becomes increasingly difficult to move. The kidney reservoir is empty and this means the end of childbearing.

In the following years of life, human uses mainly the energy of life from food and breathing air. The number of years of his life now depends on his success in these processes. 
The term time refers to modern human. This is the individual to whom the Creator has set the end of life at 120 years (Biblia Polska , Genesis, 6:3, p. 11). It is a fact that this number of years is unequivocally confirmed by neurobiological research (Jan Vijg and Eric Le Bourg, 2017) pointing exactly to the number 120 years as the statistical maximum for the human organism. This knowledge has been common knowledge for a long time. For example, Harish Johari (1997, p. 19) writes: "According to the scriptures of Svara Yoga, the lifespan of a human being is measured not in years but in the number of breaths. When we breathe 15 times a minute, human life spans 946 billion breaths - a whole 120 years." Therefore, the end of the process of transformation that defines the course of time reaches 120 years, which is the number that is encountered in the memory of human civilization. The existence of this limit number of years creates another possibility of testing the constant $\mathrm{a}=0.08$ [1/year].

Time defined as the process of energy transformation is not absolute. This time is indeed connected with the human being who is distinguished from other animate beings by the highest level of consciousness. Time is absolutely connected with the consciousness of the human as well as with the calendar which is a product of this consciousness. Only for the human the time is flowing at the rate of 0.08 [1/year]. Nevertheless this general formula concerns every animated being, but the tempo of the passage of the time is peculiar for every species. For example, dogs of race Labrador, Shepherd Dog and similar, which life span reaches 15 years, characterize different size of the rate of passing the time; at the level close to 0.20 .

The calculation shows that after 120 years the transformation going on at the rate of 0.08 [1/year] disappears, in fact its numerical magnitude is only 0.0000677 . This determines the potential end of human life. It is known, however, that the real average human life expectancy reaches 85 years, which means that there is still a lot of potential for life extension. This issue was raised by Erwin Schrödinger (1944) asking a perverse question why human lives so long? He considered that if an organism seems to be something puzzling, it is mainly because it does not quickly fall into a disorderly state of equilibrium. He asks, what causes a living organism to avoid dying? And he answers:

Any process or event, never mind the name, anything that happens in nature leads to an increase in entropy in that space in which it takes place. Thus every living organism produces positive entropy and its entropy constantly increases. It approaches the state of maximum entropy, i.e., death, and it can only stay alive by drawing negative entropy from its environment, which is something positive for it. It is it that feeds it.

The author justifies the use of the term of negative entropy by using L. Boltzman's formula in the form $\mathrm{Sn}=\mathrm{k} \times \ln \mathrm{D}-1$, where $\mathrm{D}-1$ is the inverse of the disorder measure D (colloquial formulation), $\mathrm{Sn}$ - negative entropy. It is very valuable that this outstanding European intellectualist paid attention to human's use of "tidiness" existing in nature or created consciously by human. Such things are undoubtedly medicines for diseases, vitamins and various dietary supplements. The latter are significantly used by elderly people, whose organisms have to some extent lost the ability to sufficiently absorb these compounds from food. It should be noted, however, that this satiation with tidiness, of which E. Schrödinger writes, has been reasonably applied since the beginnings of civilization, and consisted in taking care of the balance of the elements.

Figure 1 shows three lines. Line $\mathrm{E}$ is a graph of initial energy fading at a rate determined by a constant. Line $\mathrm{P}$ is a graph of available power. Line $\mathrm{H}$ illustrates the economic value of human capital shown as a percentage of the maximum at $\mathrm{t}=70$ years.

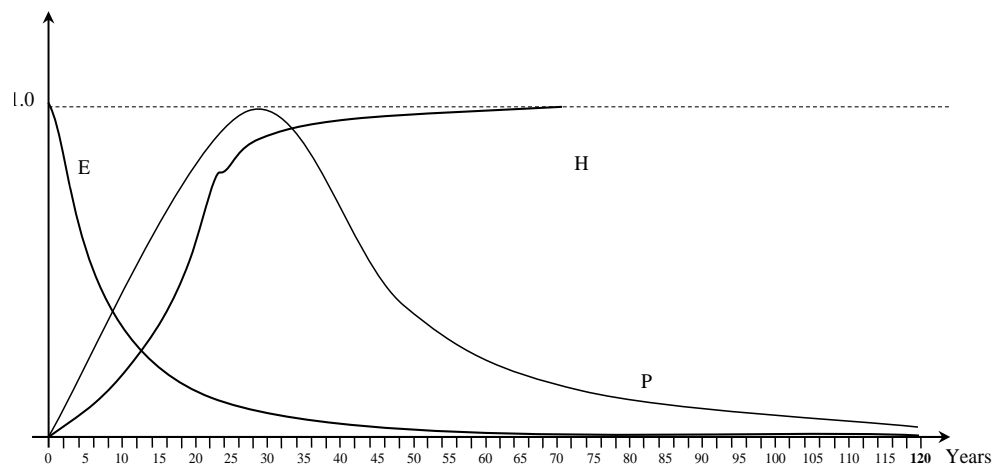

Fig. 1: The Disappearance of Primary Vital Energy and the Course of Disposable Power in the Human Body.

According to the research of M. Mazur (1976, pp. 224-234), dispositional power is equal to physiological power minus idle power. In turn, this power is proportional to the quantity and quality of the body's material. The deterioration of the quality of the material is compensated by the expansion of the organism. It is understandable that the idle power must be the greater the quantity of material. Therefore, the dispositional power reaches its maximum and then tends to zero.

The figure 1 shows that initially the line P runs similarly to the line 1 - E. Then the increasing idle power decreases the rate of increase of available power. The same reason causes the line $\mathrm{P}$ to reach its flat maximum in order to start a slow decline when the number of years exceeds 30. M. Mazur used physiological data to determine the maximum power of the average organism, which falls in the years 27-35. In these years the primary energy is respectively: 0.1153 and 0.0608 .

During the period of diminishing power of the organism, human has possibilities to delay the rate of decline by taking care to obtain the energy of life through food, respiration and other means. He/she can use the negentropy available in nature, which E. Schrödinger writes about in the mentioned essay about life (1944).

The $\mathrm{H}$ line represents the growth of personal human capital, that visible effect of the transformation of life energy into the ability to perform work in the material world. In a physically and mentally healthy person, personal human capital increases, despite the passage of time. People work, start families, settle homes, raise descendants, and often create various works of art. The examples of Isaac Newton and Wolfgang G. Leibniz are the most prominent. They left no descendants, but created intellectual works of priceless value. And this capital has multiplied and continues to this day.

Now let's answer the question, what remains of Newton's original definition of time? It turns out that a lot. There is time as a thermodynamic process that proceeds at an equal rate determined by a constant. It is not absolute, as already stated by Leibniz and Kant, it is related to modern human and his consciousness. Time is a process of thermodynamic transformation of human energy. As Newton believed, it flows evenly regardless of other events at a constant, mathematically determined pace and the calendar links the passage of time with the present position of the planet Earth in relation to the Sun. The knowledge of the passage of time and the calendar are inalienable elements of human civilisation. 


\section{Mention of concepts of time in physical theories}

The knowledge presented so far has been about the time of human of the planet Earth. This knowledge contains explanations necessary for every person and the civilization he creates. It contains coherent and complete explanations compatible with human experience and common sense. However, it is necessary to refer to physical theories in which the category of time plays an important role. To them belongs first of all the theory of relativity. In this stream of research, whose absolute leader is Albert Einstein (1879-1955), time is defined as what good clocks measure.

Consistently respecting this view, Einstein introduced a theoretical construct called "space-time" and authored the special and general theories of relativity. The latter, which is actually a theory of gravity, came about due to Einstein's brilliant intellect, but was made possible by the genius of Bernhard Riemann (1826-1866), who created the mathematical foundations of geometry in multidimensional space in particular the tools for measuring curvature (Kaku, 1994, p. 45; Debryshire, 2003, pp. 156-158).

As M. Kaku writes (1994, p. 63) "Riemann concluded that electricity, magnetism and gravity are the result of the wrinkling of our threedimensional Universe in the fourth invisible dimension." A. Einstein arrived at the equations of the general theory of relativity in parallel with David Hilbert (1862-1943) and is the main author of this theory (Kragh, 2016, pp. 146-150). He also introduced the famous formula $\mathrm{E}=\mathrm{mc}^{2}$ to science in 1905 .

The remarkable successes of the theory of relativity do not correspond with the enigmatic definition of time, and this is a natural reason for controversy, if only from scholars questioning the existence of time as a fundamental quantity in physical theories. This is clearly expressed by Julian Barbour (1999, p. 225):

The theory of relativity is not at all concerned with the abstract concept of time: it describes physical devices called clocks. There is nothing implausible in the idea that clocks moving past us at high speed should appear to go slower than the watch we wear on our hand. The movement of a clock could change the rate of its ticking.

Nevertheless, many authors give little recognition to this problem and take the disruption of the clock due to the inflow of kinetic energy as a slowing down of the passage of time. For example, Fritjof Capra (1976, p. 187) writes:

(...) What is true for lengths is also true for time intervals. They, too, depend on the frame of reference, but contrary to special distances they become longer as the velocity relative to the observer increases. This means that clocks in motion run slower; time slows down. This clock can be of ranging types: mechanical clocks, atomic clocks or even a human heart beat (...)

Further the author zealously develops the "twin paradox". He strengthens his argument as follows:

(...) The slowing down of clocks in motion, unbelievable as it sounds, is well tested in particle physics. Most of the subatomic particles are unstable, i.e. they disintegrate after a certain time into other particles. Numerous experiments have confirmed the fact that the lifetime of such an unstable particle depends on its state of motion. It increases with the speed of the particle (...)

What is so strange about a particle under kinetic energy lasting longer? How can such extrapolations be made and transfer these judgments to human life?

Einstein derived a transformation formula for the mass of an electron as a function of velocity v (Kragh, 2016, p. 134):

$m(v)=\frac{m_{0}}{\sqrt{1}-\beta^{2}}=m_{0}\left(1+\frac{1}{2} \beta^{2}+\frac{3}{8} \beta^{4}\right)$

Where: $\beta=\mathrm{v} / \mathrm{c}, \mathrm{c}-$ the speed of light.

Standing on the ground of mechanics, we will calculate how kinetic energy changes the total energy of a mechanical clock. Summing the rest energy $\mathrm{moc}^{2}$ of an object with the kinetic energy $\mathrm{mov}^{2} / 2$ we get the total energy $\mathrm{E}_{\mathrm{c}}$ (Dobija, 2010):

$E_{c}=m_{0} c^{2}+\frac{m_{0} v^{2}}{2}=m_{0} c^{2}\left(1+\frac{v^{2}}{2 c^{2}}\right)$

Where: $\mathrm{m}_{0}$ - rest mass, $\mathrm{v}$ - velocity of the object.

With respect to a mechanical clock, it can be said that with increasing velocity the mass increases to a magnitude of $m(v)=m_{0}\left(1+\frac{v^{2}}{2 c^{2}}\right)$, so a clock scaled earlier at mass $m_{0}$ is likely to be delayed. This has nothing to do with time, which flows at its own pace, but not for a clock, but for a conscious human. Notice also that at a speed of, say, $50000 \mathrm{~km} / \mathrm{sec}$ the increment calculated according to formula (3) is 0.013888889 and the value obtained from formula (2) is 0.014185106 so the result obtained on the grounds of mechanics is almost no different from the result from the theory of relativity.

Formula (3) also indicates that at $\mathrm{v}=\mathrm{c}$ the mass increases by $1 / 2$, which is not necessarily true. Just as it is not true that an object with more mass falls faster than an object with less mass, even though the gravitational force formula indicates this. The opposite effect is exerted by the second law of dynamics, so objects fall at the same rate.

It is not excluded that the human body under the influence of kinetic energy can temporarily work more efficiently, and the person can feel it. For example, it may happen that a baby after a meal subjected to energetic movements avoids colic. Apparently, this young organism, full of life energy, is able to use the supply of kinetic energy to improve digestion. Similarly, a short car ride often improves a person's mood. On the other hand, it is difficult to imagine that a human being would experience movement at $1 / 3$ the speed of light. There is no basis for the statement that human will age more slowly under the influence of the speed of motion, that the entropy of the organism will stop growing, even though it is an open system.

It is difficult to make a factual reference to the stream of research on the issue of time, in which it is suggested that time does not exist. One can trust the authority of K. Gödel (Holt, 2019, pp. 12-13), who, solving the equations of general relativity theory, came to the conclusion that time does not exist. But this conclusion is derived from the possible behaviour of the Universe, which is described by one of the solutions of Einstein's tensor equation. J. Barbour dealing professionally with the question of the existence of time engages the most significant physical and cosmological theories and his extraordinary intellect to convince himself and his readers of the view that in modern human time and its passage can arise from absolute timelessness (Barbour, 2018, pp. 66-84). These are therefore considerations of the highest order related to the investigation of the foundations of physical reality. If even time emerges from the absolute timelessness of Platonia, which Barbour introduced, then it is indispensable for the human of planet Earth to understand time as discussed in this article. This emergence of time, as the author states, is accomplished by means of the human brain and consciousness. If so, it is necessary, first of all, to weigh the opinion of I. Kant, who regarded the concept of time as innate. If even time in the aspect of the fundamental principles of physical reality is an illusion, this illusion is necessary for the mental health of modern human. 


\section{Manifestations of the thermodynamic constant of passage of time}

The constant in question determines the rate of disappearance of the original stock of human vital forces and thus defines the passage of time perceived and experienced by people. Naturally, it is connected with the end of human life defined as 120 years, when the mentioned energy reaches biological zero (0.000067). The number 120 years is known from ancient writings, as well as from modern studies of neurobiologists and gerontologists, who unanimously point to this end of the human organism's existence. The human body is an open system, so the human and nutritional sciences still have an open topic of research on how to extend life to 120 years. The constructive side of the second principle of thermodynamics is revealed here, forcing actions that restrain entropy and preserve the exergy of human capital. These effects are visible, as we know, in European countries in the last century human life has been extended by 30 years.

It turns out that the constant in question manifests itself wherever the passage of time plays an important role, in socio-economic relations. The following issues can be indicated:

- Measuring the growth of employees' human capital;

- Theory of fair remuneration for work;

- Valuation method for the natural depreciation of tangible objects;

- Source of profit and periodical measurement of this quantity;

- Risk premium theory of investing in equities;

- Equivalent and fair lending rate;

- Decent and fair prices for agricultural products.

Studies of human capital growth and fair wages are conducted together. In these studies, the constant a $=0.08$ [1/year] and the basic equation for determining fair wages is revealed:

$\mathrm{W}(\mathrm{a})=\mathrm{a} \times \mathrm{H}(\mathrm{a}, \mathrm{t})$

Where: $\mathrm{H}(\mathrm{a}, \mathrm{t})$ - worker's capital at age $\mathrm{t}$ years, $\mathrm{W}(\mathrm{a})$ - fair wage. A review of the performed research and testing of the constant is presented in recent articles (Dobija, Renkas, 2020, 2021). There are also numerous publications containing the results of testing the constant in particular topics, as Dobija (1998, 2007, 2010, 2011), Cieślak (2008), Kozioł (2011), Kurek (2011, 2012), Renkas, (2013, 2016, 2021), Oliwkiewicz (2020), (Jedrzejczyk, 2020), (Kurek, Górowski, 2020).

\section{Conclusion}

The presented considerations show that the resignation from the feature of time absoluteness, present in Newton's conception, and its connection with human through the inalienable mediation of thermodynamics, leads to a coherent definition of this important physical, economic and social category. The constant defining the rate at which time runs binds thermodynamic time to that great achievement of mankind which is the calendar and the measures of time used. Time is not absolute and cosmic, it is instead embedded in human consciousness and human civilization. There are many indications that D. Park is right (1972, p. 111) in stating that "The passage of time does not need to be explained by physics". This is a human-wide agenda.

Modern human, aware of the passage of time, appeared on planet Earth at a certain time. This is said by Prometheus, who was given a voice by Aeschylus (Prometheus Bound, excerpt from Episodion 1).

(...)You must not think it is my stubbornness

that keeps me quiet, or a sense of pride,

for bitter thoughts keep gnawing at my heart

to see how foully I am being abused.

And yet who else but I assigned clear rights [440].

and privileges to these new deities? [540]

But I make no complaint about such things,

for if I spoke, I would be telling you

what you already know. So listen now

to all the miseries of mortal men-

how they were simple fools in earlier days,

until I gave them sense and intellect.

I will not speak of them to criticize,

but in a spirit of goodwill to show

I did them many favours. (...)

For modern human, the knowledge of the rate of transformation of the primordial energy of life (Yuan Qi), as well as the knowledge of the profile of changes in the power of the body (Fig. 1), creates a challenge to work towards increasing the number of years of healthy life. This is helped by the ability to draw energy from food and air, which has been developed from ancient times until now. The wellknown truth is confirmed that the second law of thermodynamics stimulates humanity to work wisely, the effects of which, in addition to development, make it possible to halt the increase of entropy in organisms and the environment. In this sense also time, having a thermodynamic provenance, is a creative factor in the life of people and communities.

\section{References}

[1] Barbour, J. (2018). Koniec czasu. Nowa rewolucja w fizyce (The End of Time. The Next Revolution in Physics), Copernicus Center Press, Kraków.

[2] Capra, F. (1982). The Tao of Physics: An Exploration of the Parallels between Modern Physics and Eastern Mysticism, Flamingo, London.

[3] Cieslak, I. (2008). Value of Human Capital and Wage Disparities [w:] Górowski I. (ed.), General Accounting Theory Evolution and Design for Efficiency, pp. 289-303, Warszawa, Wydawnictwa Akademickie i Profesjonalne.

[4] Aeschylus, (2012). Prometheus bound, Translated by I. Johnston, Vancouver Island University, Nanaimo, BC.

[5] Derbyshire, J. (2009). Obsesja liczb pierwszych. Bernhard Riemann i największy nierozwiazany problem w matematyce (Prime Obsession: Berhhard Riemann and the Greatest Unsolved Problem in Mathematics), Wydawnictwo: NAKOM, Poznań. 
[6] Dobija, M. (1998). How to place human resources into the balance sheet. Journal of Human Resource Costing \& Accounting, 3(1), 83-92. https://doi.org/10.1108/eb029044.

[7] Dobija, M. (2007). Abstract nature of capital and money, [in:] L.M. Cornwall (Ed.), new developments in banking and finance (pp. 89-114). New York: Nova Science Publishers. https://doi.org/10.1108/eb029044.

[8] Dobija, M. (2010). Natura czasu a kwoty amortyzacji środków trwałych (The Nature of Time and Depreciation Rates of Fixed Assets), Zeszyty Naukowe Uniwersytetu Ekonomicznego w Krakowie, nr 829, ss. 5-20.

[9] Dobija, M. (2011). Labor Productivity vs. Minimum Wage Level, Modern Economy, Vol.2, No 2, pp. $780-787$. https://doi.org/10.4236/me.2011.25086.

[10] Dobija, M. (2015). Laborism. The Economics Driven by Labor, Modern Economy, no. 6, pp. 578-594, https://doi.org/10.4236/me.2015.65056.

[11] Dobija, M., Renkas, J. (2021). How the inclusion of thermodynamic principles recovers economic sciences, International Journal of Accounting and Economics Studies, vol. 9(2), pp. 21-31, 2021.

[12] Dobija, M., Renkas, J. (2021). The thermodynamic principles as the theoretical basis of fair remuneration, International Journal of Physical Research, vol. 9(1), pp. 1-6, 2021. https://doi.org/10.14419/ijpr.v9i1.31247.

[13] Goetzmann, W.N., Ibbotson, R.G. (2006). History and the Equity Risk Premium, [in:] Goetzmann, W.N., Ibbotson, R.G. (ed.), the Equity Risk Premium: Essays and Explorations, Yale School of Management, Oxford University Press.

[14] Holt, J. (2018). When Einstein Walked with Gödel: Excursions to the Edge of Thought, Farrar, Straus and Giroux, New York.

[15] Huai-Chin, Nan. (1984). Tao \& Longevity: Mind-Body Transformation, Rebis Publishing House, Poznań

[16] Jan Vijg, Eric Le Bourg (2017). Aging and the Inevitable Limit to Human Life Span, Gerontology, pp. 432-434, 63(5), https://doi.org/10.1159/000477210.

[17] Jędrzejczyk, M. (2020). Capital, Work, and Economic Value in the Context of the First and Second Law of Thermodynamics, Thermodynamics 2.0. International Conference, June 2020, Worcester, https://www.youtube.com/channel/UCJC98pmGjTo-xYP99MkLtrg/videos

[18] Johari, H. (1977). Breath, Mind and Consciousness, Dom Wydawniczy Limbus, Bydgoszcz.

[19] Kaku, M. (1994). Hyperspace: A Scientific Odyssey through Parallel Universe, Time Warps and the Tenth Dimension. New York: Doubleday.

[20] Kozioł, W. (2011). Constant of potential growth in the calculation of human capital (Polish language: Stała potencjalnego wzrostu w rachunku kapitału ludzkiego), Nierówności Społeczne w Wzrost Gospodarczy, Uniwersytet Rzeszowski, Zeszyt nr 19, s. 252-260.

[21] Kragh, H. (2016). Wielkie spekulacje. Teorie i nieudane rewolucje w fizyce i kosmologii (Higher Speculations: Grand Theories and Failed Revolutions in Physics and Cosmology), Copernicus Center Press, Kraków.

[22] Kurek, B. (2011). The deterministic risk premium hypothesis, Cracow: Monografie, Wydawnictwo Uniwersytetu Ekonomicznego w Krakowie.

[23] Kurek, B. (2012). An estimation of the capital growth rate in business activities. Modern Economy, 3(4), 364-372. doi: 10.4236/me.2012.34047. https://doi.org/10.4236/me.2012.34047.

[24] Kurek, B., Górowski, I. (2020). Importance of Gender, Location of Secondary School, and Professional Experience for GPA - A Survey of Students in a Free Tertiary Education Setting, Sustainability, 12, no. 21: 9224. https://doi.org/10.3390/su12219224.

[25] Maoshing, Ni. (2012). The Yellow Emperor's Classic of Medicine (Polish edition), Wydawnictwo Galaktyka, Łódź

[26] Oliwkiewicz, B. (2020). Salary expectations vs. fair wages of economics graduates (Polish language: Oczekiwania płacowe a godziwe wynagrodzenia absolwentów studiów ekonomicznych) [in:] Zarządzanie zrównoważonym rozwojem organizacji, (red.) D. Fatuła, Oficyna Wydawnicza AFM, Kraków, s. 67-94.

[27] Park, D. (1972). The myth of the passage of time, [In:] J.T. Fraser, F. Haber \& G. Muller (eds.), The Study of Time (pp. 110-121), Springer Verlag. https://doi.org/10.1007/978-3-642-65387-2 7.

[28] Pitchford, P. (2008). Healing with Whole Foods (Polish language: Odżywianie dla zdrowia), Wydawnictwo Galaktyka, Łódź.

[29] Renkas, J. (2013). Wage expectations in light of human capital measurement theory. Argumenta Oeconomica Cracoviensia, 9(9), 29-42. https://doi.org/10.15678/AOC.2013.0902.

[30] Renkas, J. (2016). Wage inequalities and the economic constant of potential growth (Polish language: Nierówności płacowe a stała ekonomiczna potencjalnego wzrostu), Nierówności Społeczne a Wzrost Gospodarczy, Zeszyt nr 47(3), pp. 466-480, https://doi.org/10.15584/nsawg.2016.3.34.

[31] Renkas, J. (2021). An Econometric versus Thermodynamic Approach to Modeling Wage Expectations, Innovation Management and Information Technology Impact on Global Economy in the Era of Pandemic: Proceedings of the 37th International Business Information Management Association Conference (IBIMA), 30-31 May 2021 Cordoba, Spain, [ed.] Khalid S. Soliman, PA: International Business Information Management Association, pp. 5879-5887.

[32] Schrödinger, E. (1944). What is life? The Physical Aspect of the Living Cell. Based on lectures delivered under the auspices of the Dublin Institute for Advanced Studies at Trinity College, Dublin, in February 1943, http://www.whatislife.ie/downloads/What-is-Life.pdf (access date: 06.10.2021). 